\title{
Knoevenagel Condensation of Aldehydes with Ethyl Cyanoacetate in Water Catalyzed by $\mathrm{P4VP} / \mathrm{Al}_{2} \mathrm{O}_{3}-\mathrm{SiO}_{2}$
}

\author{
Majid Kolahdoozan, ${ }^{1,2}$ Roozbeh Javad Kalbasi, ${ }^{1}$ Zohreh S. Shahzeidi, ${ }^{1}$ and Farzad Zamani1 \\ ${ }^{1}$ Department of Chemistry, Shahreza Branch, Islamic Azad University, Isfahan,Shahreza 311-86145, Iran \\ ${ }^{2}$ Young Researcher Club, Shahreza Branch, Islamic Azad University, Isfahan,Shahreza 311-86145, Iran \\ Correspondence should be addressed to Majid Kolahdoozan; kolahdoozan@iaush.ac.ir
}

Received 28 June 2012; Revised 9 September 2012; Accepted 25 September 2012

Academic Editor: Radhey Srivastava

Copyright (C) 2013 Majid Kolahdoozan et al. This is an open access article distributed under the Creative Commons Attribution License, which permits unrestricted use, distribution, and reproduction in any medium, provided the original work is properly cited.

This paper reports the preparation and characterization of poly(4-vinylpyridine) (P4VP) supported on $\mathrm{Al}_{2} \mathrm{O}_{3}-\mathrm{SiO}_{2}$ and its application for Knoevenagel condensation reaction of various aldehydes with ethyl cyanoacetate in water as a green solvent. The results illustrate that the sample containing 0.6 molar ratio of Al to Si exhibits the highest yield (98\%) in the reaction of benzaldehyde with ethyl cyanoacetate with $100 \%$ selectivity to the arylidene derivative.

\section{Introduction}

The development of heterogeneous catalysts for special chemical synthesis has become a major area of research. The potential advantage of these materials (simplified recovery and reusability) over homogeneous systems can lead to environmentally benign chemical procedures in academia and industries. The application of solid acidic and basic catalysts in clean technologies and sustainable chemistry is a green alternative for chemical processes. The materials provide high yield and selectivity along with waste reduction, easier catalyst recovery procedures, and safer and easier operation methods.

Recently, many attempts have been made to develop polymer-supported catalysts on inorganic surfaces. It provides convenience of workup and product purification, lower environmental hazards, and in most cases, reusability of the polymer-supported catalysts. These materials combine some advantages of organic compounds (easy processing with conventional techniques, elasticity, and organic functionalities) with properties of inorganic oxides (hardness, thermal and chemical stability, and transparency). Therefore, they have attracted considerable attention $[1,2]$. Moreover, the use of these materials offers a striking and practical method for clean and efficient preparation of novel chemical libraries with potential application in the pharmaceutical or agrochemical industries.

The Knoevenagel condensation reaction is one of the most important $\mathrm{C}-\mathrm{C}$ bond-forming reactions in organic chemistry. In general, this type of condensation reaction performs in homogeneous solution in the presence of organic bases [3]. This method has its limitations such as difficulties in catalyst separation and recycling. In order to reduce effluents to environmentally acceptable limits, this transformation has been studied by using various heterogeneous solid bases [4], for instance, hydrotalcite [5], hydroxyapatiteencapsulated $\gamma-\mathrm{Fe}_{2} \mathrm{O}_{3}$ [6], MCM-41 [7], modified silica gel [8], $\mathrm{MgO} / \mathrm{ZrO}_{2}$ [9], and guanidine [10].

In the present study, to develop heterogeneous basic catalysts on mesoporous material $[11,12]$, here, we report the synthesis and characterization of poly(4-vinylpyridine $) / \mathrm{Al}_{2} \mathrm{O}_{3}-\mathrm{SiO}_{2} \quad\left(\mathrm{P} 4 \mathrm{VP} / \mathrm{Al}_{2} \mathrm{O}_{3}-\mathrm{SiO}_{2}\right)$ as a nano-pore catalyst by in situ polymerization of 4 -vinylpyridine in the presence of Si and Al precursors. The catalytic performance of the nano composite was investigated for the Knoevenagel condensation of some aromatic and aliphatic aldehydes with active methylene reagents. In addition, catalytic activity of the composites prepared through two methods (in situ and impregnated methods) was investigated, and also a comparison was made between the basic catalytic properties 
of $\mathrm{P} 4 \mathrm{VP} / \mathrm{Al}_{2} \mathrm{O}_{3}-\mathrm{SiO}_{2}, \mathrm{P} 4 \mathrm{VP} / \mathrm{Al}_{2} \mathrm{O}_{3}$, and $\mathrm{P} 4 \mathrm{VP} / \mathrm{SiO}_{2}$ composites.

\section{Experimental}

2.1. Techniques. The obtained materials were characterized by X-ray diffraction (Bruker D8ADVANCE, $\mathrm{Cu} \mathrm{K} \alpha$ radiation), FT-IR spectroscopy (Nicolet 400D in $\mathrm{KBr}$ matrix in the range of $4000-400 \mathrm{~cm}^{-1}$ ), BET specific surface areas and $\mathrm{BJH}$ pore size distribution (Series BEL SORP 18, at $77 \mathrm{~K}$ ), scanning electron microscopy using PhilipsXL30 with SE detector, and back titration using $\mathrm{NaOH}(0.1 \mathrm{~N})$.

\subsection{Catalyst Preparation}

2.2.1. Synthesis of $\mathrm{P} 4 \mathrm{VP} / \mathrm{Al}_{2} \mathrm{O}_{3}-\mathrm{SiO}_{2}$ by In Situ Method. Aluminum isopropoxide (98\%) $(2 \mathrm{~mL}, 10 \mathrm{mmol})$ was dissolved in $n$-butanol $(60 \mathrm{~mL})$ in a round-bottom flask equipped with magnetic stirrer and a condenser. The mixture was heated to $80^{\circ} \mathrm{C}$. Then, to the clear solution, acetyl acetone $(\mathrm{H}$-acac, $2.064 \mathrm{~mL}, 0.02 \mathrm{~mol})$ and tetraethyl orthosilicate $(98 \%)(2 \mathrm{~mL}$, $10 \mathrm{mmol}$ ) were added sequentially and rapidly. Following the addition, a transparent solution was observed after 5 minutes of stirring. Then, 4-vinylpyridine $(2 \mathrm{~mL}, 18.5 \mathrm{mmol})$ and potassium peroxodisulfate $(0.5 \mathrm{~g}, 1.85 \mathrm{mmol})$ were added to the reaction mixture under continuous stirring at $80^{\circ} \mathrm{C}$. After $1 \mathrm{~h}$, the solution was cooled down to room temperature, and deionized water $(10 \mathrm{~mL})$ was added slowly as the hydrolyzing agent. The solution was left for 48 hours at room temperature to hydrolyze the alkoxides, yielding a transparent gel. It was dried at $60^{\circ} \mathrm{C}$, and white fine solid powder was obtained. By varying the $\mathrm{Al} / \mathrm{Si}$ molar ratio from 1.66 to 0.6 , various $\mathrm{P} 4 \mathrm{VPs} / \mathrm{Al}_{2} \mathrm{O}_{3}-\mathrm{SiO}_{2}$ were also prepared for comparative purposes. The samples were named $\mathrm{P} 4 \mathrm{VP} / \mathrm{Al}_{2} \mathrm{O}_{3}-\mathrm{SiO}_{2}(x)$ (in situ) (where $x=\mathrm{Al} / \mathrm{Si}$ molar ratio which varies from 1.66 to $0.6)$.

The amount of basic sites of the polymer-supported samples was estimated by back titration using $\mathrm{NaOH}(0.1 \mathrm{~N})$. The distinct amount of the catalyst was stirred in $\mathrm{HCl}$ $(0.5 \mathrm{~N})$ for 30 minutes. Then, the mixture was filtrated and titrated with $\mathrm{NaOH}(0.1 \mathrm{~N})$. The amounts of basic sites of $\mathrm{P} 4 \mathrm{VP} / \mathrm{Al}_{2} \mathrm{O}_{3}-\mathrm{SiO}_{2}\left(1.66\right.$ ) (in situ), $\mathrm{P} 4 \mathrm{VP} / \mathrm{Al}_{2} \mathrm{O}_{3}-\mathrm{SiO}_{2}$ (1) (in situ), and $\mathrm{P} 4 \mathrm{VP} / \mathrm{Al}_{2} \mathrm{O}_{3}-\mathrm{SiO}_{2}(0.6)$ (in situ) were found to be $4.95,5.15$, and $5.86 \mathrm{mmol} \mathrm{g}^{-1}$, respectively.

2.2.2. Synthesis of $\mathrm{P} 4 \mathrm{VP} / \mathrm{SiO}$ by In Situ Method. Tetraethyl orthosilicate $(98 \%)(2 \mathrm{~mL}, 9 \mathrm{mmol})$ and ethanol $(2.3 \mathrm{~mL}$, $45 \mathrm{mmol}$ ) were stirred at room temperature. Then, the mixture of $2 \mathrm{~mL}$ of 4 -vinylpyridine, potassium peroxodisulfate $(0.5 \mathrm{~g}, 1.85 \mathrm{mmol})$, and $1.05 \mathrm{~mL}$ of aqueous nitric acid $\left(0.05 \mathrm{~mL} \mathrm{HNO}_{3}\right.$ and $\left.1 \mathrm{~mL} \mathrm{H}_{2} \mathrm{O}\right)$ slowly added was stirred at room temperature for 30 minutes. The solution was heated to $80^{\circ} \mathrm{C}$, and the components were thoroughly mixed. After 2 hours, the reaction mixture was cooled down to room temperature, and ethanol $(5.11 \mathrm{~mL}, 100 \mathrm{mmol})$ was added slowly. The resulting solid product was filtered and washed with deionized water and then dried at $60^{\circ} \mathrm{C}$. The sample was named as $\mathrm{P} 4 \mathrm{VP} / \mathrm{SiO}_{2}$, and the amount of basic sites was $2.26 \mathrm{mmol} \mathrm{g}^{-1}$.

2.2.3. Synthesis of $\mathrm{P} 4 \mathrm{VP} / \mathrm{Al}_{2} \mathrm{O}_{3}$ by In Situ Method. For the preparation of another base catalyst, the relevant aluminum isopropoxide (98\%) was used to reach the same molar ratio as it was done for $\mathrm{P} 4 \mathrm{VP} / \mathrm{SiO}_{2}$. The obtained sample was termed as $\mathrm{P} 4 \mathrm{VP} / \mathrm{Al}_{2} \mathrm{O}_{3}$, and the amount of basic sites was $2.75 \mathrm{mmol} \mathrm{g}^{-1}$.

2.2.4. Synthesis of $\mathrm{P} 4 \mathrm{VP} / \mathrm{Al}_{2} \mathrm{O}_{3}-\mathrm{SiO}_{2}$ by Impregnated Method. $\mathrm{Al}_{2} \mathrm{O}_{3}-\mathrm{SiO}_{2}$ was used as the support, which was prepared by the optimized Al/Si molar ratio, described in the previous work $[12,13]$. A mixture of 4-vinylpyridine $(2 \mathrm{~mL}$, $18.5 \mathrm{mmol})$ and benzoyl peroxide $(0.134 \mathrm{~g}, 0.556 \mathrm{mmol})$ in $15 \mathrm{~mL}$ of tetrahydrofuran (THF) was refluxed by stirring it for 4 hours. In this step, poly(4-vinylpyridine) was produced. Then, $\mathrm{Al}_{2} \mathrm{O}_{3}-\mathrm{SiO}_{2}(0.6)$ (1.6 g) was added to the reaction mixture, and it was refluxed for another 2 hours. On completion, the solvent was removed by vacuum filtration and, the residue was washed by tetrahydrofuran $(3 \times 10 \mathrm{~mL})$ and dried at $60^{\circ} \mathrm{C}$ under reduced pressure. The sample was termed as $\mathrm{P} 4 \mathrm{VP} / \mathrm{Al}_{2} \mathrm{O}_{3}-\mathrm{SiO}_{2}(0.6)$ (imp), and the amount of basic sites was $1.32 \mathrm{mmol} \mathrm{g}^{-1}$.

\subsection{General Procedure for the Knoevenagel Condensation.} In a typical experiment, $2 \mathrm{mmol}$ of benzaldehyde $(0.20 \mathrm{~mL})$, $2 \mathrm{mmol}$ of ethyl cyanoacetate $(0.21 \mathrm{~mL})$, and $0.04 \mathrm{~g}$ of catalyst $\left(\mathrm{P} 4 \mathrm{VP} / \mathrm{Al}_{2} \mathrm{O}_{3}-\mathrm{SiO}_{2}\right)$ taken in a round-bottom flask were refluxed under continuous stirring in $\mathrm{H}_{2} \mathrm{O}$ as a solvent. The progress and completion of the reaction was monitored by TLC, using $n$-hexane/ethyl acetate $(5: 1)$ as an eluent. 30 minutes after the reaction, the mixture was cooled to $10^{\circ} \mathrm{C}$ for the purpose of solidification of the product, water was also removed by Buchner filtration. Afterwards, the residual solid was recrystallized by hot ethanol $(5 \mathrm{~mL})$, and the product was identified by ${ }^{1} \mathrm{H}-\mathrm{NMR},{ }^{13} \mathrm{C}-\mathrm{NMR}$, and FT-IR spectroscopic techniques. The spectral data of some desired products are given as follows.

2-Propenoic Acid-2-Cyano-3-Phenyl Ethyl Ester (Table 7, Entry 1). White crystal solid, $\mathrm{mp} 49-51^{\circ} \mathrm{C} ;\left(\mathrm{KBr}, \mathrm{cm}^{-1}\right): 1446$, 1606 (C=C, aromatic), $1733(\mathrm{C}=\mathrm{O}), 2221(\mathrm{CN}), 2982(\mathrm{CH}$, str), 3029 (=CH, str), $3069\left(\mathrm{CH}\right.$, str, aromatic); ${ }^{1} \mathrm{H}-\mathrm{NMR}$ $\left(500 \mathrm{MHz}, \mathrm{CDCl}_{3}\right) \delta 1.43\left(\mathrm{CH}_{3}, \mathrm{t}, 3 \mathrm{H}, J=7.1 \mathrm{~Hz}\right), 4.42\left(\mathrm{CH}_{2}\right.$, q, $2 \mathrm{H}, J=7.1 \mathrm{~Hz}), 7.52-7.60(\mathrm{ArH}, \mathrm{m}, 3 \mathrm{H}), 8.02(\mathrm{ArH}, \mathrm{d}, 2 \mathrm{H}$, $J=7.4 \mathrm{~Hz}), 8.28(=\mathrm{CH}, \mathrm{s}, 1 \mathrm{H}) ;{ }^{13} \mathrm{C}-\mathrm{NMR}\left(125 \mathrm{MHz}, \mathrm{CDCl}_{3}\right)$ $\delta 14.59\left(\mathrm{CH}_{3}\right), 63.15\left(\mathrm{O}-\mathrm{CH}_{2}\right), 103.49(\mathrm{C}-\mathrm{CN}), 115.90(\mathrm{CN})$, $129.71,131.49,131.92,133.72,155.44,162.89(\mathrm{C}=\mathrm{O})$.

2-Propenoic Acid-2-Cyano-3-(3-Methyl Phenyl) Ethyl Ester (Table 7, Entry 3). White crystal solid, mp 82-85 C; IR ( $\mathrm{KBr}$, $\left.\mathrm{cm}^{-1}\right): 1450,1609(\mathrm{C}=\mathrm{C}$, aromatic $), 1728(\mathrm{C}=\mathrm{O}), 2218(\mathrm{CN})$, 2908, 2982 (CH, str), 3022 (=CH, str); ${ }^{1} \mathrm{H}-\mathrm{NMR}(500 \mathrm{MHz}$, $\left.\mathrm{CDCl}_{3}\right) \delta 1.44\left(\mathrm{CH}_{3}, \mathrm{t}, 3 \mathrm{H}, J=7.1 \mathrm{~Hz}\right), 2.45\left(\mathrm{CH}_{3}, \mathrm{~s}, 3 \mathrm{H}\right)$, $4.42\left(\mathrm{CH}_{2}, \mathrm{q}, 2 \mathrm{H}, \mathrm{J}=7.1 \mathrm{~Hz}\right), 7.39-7.44(\mathrm{ArH}, \mathrm{m}, 2 \mathrm{H}), 7.81$ $(\mathrm{ArH}, \mathrm{s}, 1 \mathrm{H}), 7.85(\mathrm{ArH}, \mathrm{d}, 1 \mathrm{H}, J=7.3 \mathrm{~Hz}), 8.25(=\mathrm{CH}$, 
s, $1 \mathrm{H}) ;{ }^{13} \mathrm{C}-\mathrm{NMR}\left(125 \mathrm{MHz}, \mathrm{CDCl}_{3}\right) \delta 14.59\left(\mathrm{CH}_{3}\right), 21.71$ $\left(\mathrm{CH}_{3}\right.$, aromatic), $63.11\left(\mathrm{O}-\mathrm{CH}_{2}\right), 103.12(\mathrm{C}-\mathrm{CN}), 115.97$ $(\mathrm{CN}), 128.66,129.59,131.91,132.12,134.64,139.56,155.70$, $163.04(\mathrm{C}=\mathrm{O})$.

2-Propenoic Acid-2-Cyano-3-(4-Methoxy Phenyl) Ethyl Ester (Table 7, Entry 5). White crystal solid, $\mathrm{mp} 81-82^{\circ} \mathrm{C}$; IR $(\mathrm{KBr}$, $\left.\mathrm{cm}^{-1}\right)$ : 1435, 1510, $1585(\mathrm{C}=\mathrm{C}$, aromatic), $1722(\mathrm{C}=\mathrm{O}), 2213$ (CN), 2841, 2990 (CH, str.), 3021 (=CH, str.); ${ }^{1} \mathrm{H}-\mathrm{NMR}$ $\left(500 \mathrm{MHz}, \mathrm{CDCl}_{3}\right) \delta 1.43\left(\mathrm{CH}_{3}, \mathrm{t}, 3 \mathrm{H}, J=7.1 \mathrm{~Hz}\right), 3.93$ $\left(\mathrm{CH}_{3} \mathrm{O}, \mathrm{s}, 3 \mathrm{H}\right), 4.40\left(\mathrm{CH}_{2}, \mathrm{q}, 2 \mathrm{H}, J=7.1 \mathrm{~Hz}\right), 7.03(\mathrm{ArH}$, d, $2 \mathrm{H}, J=8.9 \mathrm{~Hz}), 8.04(\mathrm{ArH}, \mathrm{d}, 2 \mathrm{H}, J=8.9 \mathrm{~Hz}), 8.21$ $(=\mathrm{CH}, \mathrm{s}, 1 \mathrm{H}) ;{ }^{13} \mathrm{C}-\mathrm{NMR}\left(125 \mathrm{MHz}, \mathrm{CDCl}_{3}\right) \delta 14.63\left(\mathrm{CH}_{3}\right)$, $56.05\left(\mathrm{CH}_{3} \mathrm{O}\right), 62.86\left(\mathrm{O}-\mathrm{CH}_{2}\right), 99.84(\mathrm{C}-\mathrm{CN}), 116.65(\mathrm{CN})$, $115.20,124.82,134.07,154.82,164.22,163.56(\mathrm{C}=\mathrm{O})$.

2-Propenoic Acid-3-(2-Chloro Phenyl)-2-Cyano Ethyl Ester (Table 7, Entry 6). White crystal solid, mp $52-54^{\circ} \mathrm{C}$; IR $(\mathrm{KBr}$, $\left.\mathrm{cm}^{-1}\right)$ : 1470, $1603(\mathrm{C}=\mathrm{C}$, aromatic), $1728(\mathrm{C}=\mathrm{O}), 2224(\mathrm{CN})$, 2919 (CH, str.), 2992 (=CH, str.), 3064 (CH, str, aromatic); ${ }^{1} \mathrm{H}-\mathrm{NMR}\left(500 \mathrm{MHz}, \mathrm{CDCl}_{3}\right) \delta 1.44\left(\mathrm{CH}_{3}, \mathrm{t}, 3 \mathrm{H}, J=7.2 \mathrm{~Hz}\right)$, $4.44\left(\mathrm{CH}_{2}, \mathrm{q}, 2 \mathrm{H}, J=7.2 \mathrm{~Hz}\right), 7.43-7.55(\mathrm{ArH}, \mathrm{m}, 3 \mathrm{H})$, $8.27(\mathrm{ArH}, \mathrm{d}, 1 \mathrm{H}, J=7.6 \mathrm{~Hz}), 8.72(=\mathrm{CH}, \mathrm{s}, 1 \mathrm{H}) ;{ }^{13} \mathrm{C}-\mathrm{NMR}$ $\left(125 \mathrm{MHz}, \mathrm{CDCl}_{3}\right) \delta 14.56\left(\mathrm{CH}_{3}\right), 63.38\left(\mathrm{O}-\mathrm{CH}_{2}\right), 106.64$ (C-CN), 115.24 (CN), 127.89, 130.31, 130.77, 134.09, 136.87, $151.59,162.24(\mathrm{C}=\mathrm{O})$.

2-Propenoic Acid-2-Cyano-3-(4-Nitro Phenyl) Ethyl Ester (Table 7, Entry 7). Yellow crystal solid, mp $165^{\circ} \mathrm{C}$; IR $(\mathrm{KBr}$, $\left.\mathrm{cm}^{-1}\right)$ : $1516(\mathrm{C}=\mathrm{C}$, aromatic), $1722(\mathrm{C}=\mathrm{O}), 2219(\mathrm{CN}), 2990$ (CH, str.), 3096 (=CH, str.); ${ }^{1} \mathrm{H}-\mathrm{NMR}\left(500 \mathrm{MHz}, \mathrm{CDCl}_{3}\right) \delta$ $1.46\left(\mathrm{CH}_{3}, \mathrm{t}, 3 \mathrm{H}, J=7.2 \mathrm{~Hz}\right), 4.46\left(\mathrm{CH}_{2}, \mathrm{q}, 2 \mathrm{H}, J=7.2 \mathrm{~Hz}\right)$, $8.17(\mathrm{ArH}, \mathrm{d}, 2 \mathrm{H}, J=8.8 \mathrm{~Hz}), 8.34(=\mathrm{CH}, \mathrm{s}, 1 \mathrm{H}) 8.39(\mathrm{ArH}$, d, $2 \mathrm{H}, J=8.8 \mathrm{~Hz})$.

2-Propenoic Acid-2-Cyano-3-(2-Furanyl) Ethyl Ester (Table 7, Entry 8). White crystal solid, $\mathrm{mp} 85-87^{\circ} \mathrm{C}$; IR $\left(\mathrm{KBr}, \mathrm{cm}^{-1}\right)$ : 1460, 1622 (C=C, aromatic), $1722(\mathrm{C}=\mathrm{O}), 2219(\mathrm{CN}), 2990$ (CH, str.), $3034\left(=\mathrm{CH}\right.$, str.), $3133(\mathrm{CH}$, str, aromatic $) ;{ }^{1} \mathrm{H}-$ $\operatorname{NMR}\left(500 \mathrm{MHz}, \mathrm{CDCl}_{3}\right) \delta 1.40\left(\mathrm{CH}_{3}, \mathrm{t}, 3 \mathrm{H}, J=7.2 \mathrm{~Hz}\right), 4.38$ $\left(\mathrm{CH}_{2}, \mathrm{q}, 2 \mathrm{H}, J=7.1 \mathrm{~Hz}\right), 6.68(\mathrm{ArH}, \mathrm{q}, 1 \mathrm{H}, J=1.2 \mathrm{~Hz}), 7.41$ $(\mathrm{ArH}, \mathrm{d}, 1 \mathrm{H}, J=3.6 \mathrm{~Hz}), 7.77(\mathrm{ArH}, \mathrm{d}, 1 \mathrm{H}, J=1.5 \mathrm{~Hz}), 8.03$ $(=\mathrm{CH}, \mathrm{s}, 1 \mathrm{H}) ;{ }^{13} \mathrm{C}-\mathrm{NMR}\left(125 \mathrm{MHz}, \mathrm{CDCl}_{3}\right) \delta 14.58\left(\mathrm{CH}_{3}\right)$, $62.99\left(\mathrm{O}-\mathrm{CH}_{2}\right), 99.08(\mathrm{C}-\mathrm{CN}), 122.14(\mathrm{CN}), 114.28,115.75$, $139.88,148.69,149.17,163(\mathrm{C}=\mathrm{O})$.

2-Propenoic Acid-2-Cyano-3-Pentyl Ethyl Ester (Table 7, Entry 9). Colorless oil; ${ }^{1} \mathrm{H}-\mathrm{NMR}\left(500 \mathrm{MHz}, \mathrm{CDCl}_{3}\right) \delta 7.78(\mathrm{t}, J=$ $7.8 \mathrm{~Hz}, \mathrm{H}$-olefinic), 4.55 (q, $J=6.5 \mathrm{~Hz}, 2 \mathrm{H}, \mathrm{OCH}_{2} \mathrm{CH}_{3}$ ), 2.68 (q, $J=7.7 \mathrm{~Hz}, 2 \mathrm{H}, \mathrm{H}-2), 1.5(\mathrm{~m}, 2 \mathrm{H}, \mathrm{H}-3), 1.6-1.4(\mathrm{~m}, \mathrm{H}-4,5$ and $\left.\mathrm{OCH}_{2} \mathrm{CH}_{3}\right), 1.0\left(\mathrm{CH}_{3}, \mathrm{~m}, 3 \mathrm{H}\right)$.

2-Propenoic Acid-2-Cyano-3-Cyclohexyl Ethyl Ester (Table 7, Entry 10). Colorless oil; ${ }^{1} \mathrm{H}-\mathrm{NMR}\left(500 \mathrm{MHz}, \mathrm{CDCl}_{3}\right) \delta 7.48$ (d, $J=9.7 \mathrm{~Hz}, 1 \mathrm{H}, \mathrm{H}$-olefinic), $4.5(\mathrm{q}, J=7.2 \mathrm{~Hz}, 2 \mathrm{H}$, $\left.\mathrm{OCH}_{2} \mathrm{CH}_{3}\right), 2.9(\mathrm{CH}, \mathrm{m}, 1 \mathrm{H}), 1.9\left(\mathrm{CH}_{2}, \mathrm{~m}, 4 \mathrm{H}\right), 1.33(\mathrm{t}$, $\left.J=7.2 \mathrm{~Hz}, 3 \mathrm{H}, \mathrm{OCH}_{2} \mathrm{CH}_{3}\right), 1.3-1.5\left(\mathrm{CH}_{2}, \mathrm{~m}, 6 \mathrm{H}\right)$.

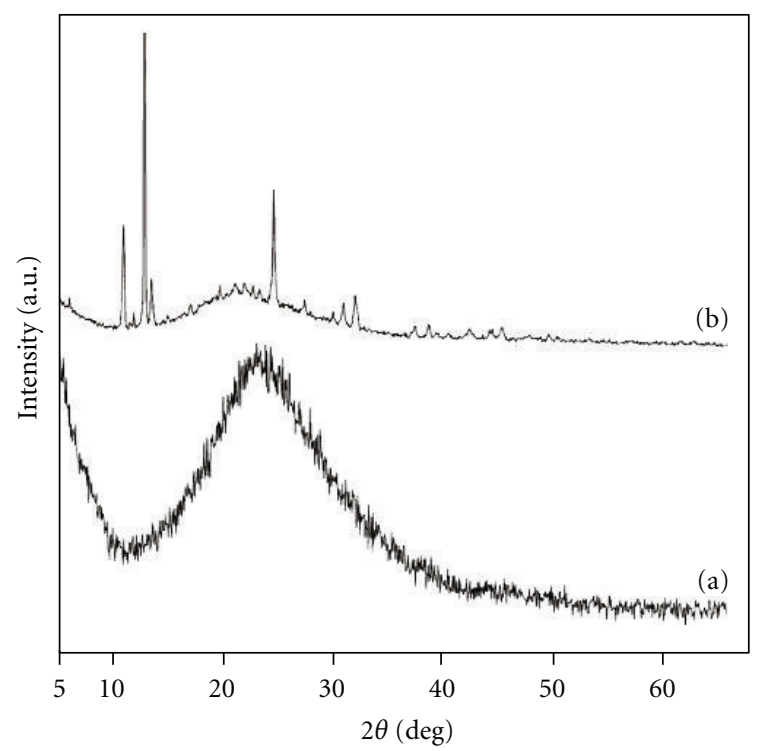

Figure 1: Powder XRD patterns of (a) $\mathrm{Al}_{2} \mathrm{O}_{3}-\mathrm{SiO}_{2}(0.6)$ and (b) $\mathrm{P} 4 \mathrm{VP} / \mathrm{Al}_{2} \mathrm{O}_{3}-\mathrm{SiO}_{2}(0.6)$ (in situ).

\section{Results and Discussion}

3.1. Characterization of the Catalyst. XRD patterns of $\mathrm{Al}_{2} \mathrm{O}_{3}$ $\mathrm{SiO}_{2}(0.6)$ and $\mathrm{P} 4 \mathrm{VP} / \mathrm{Al}_{2} \mathrm{O}_{3}-\mathrm{SiO}_{2}(0.6)$ (in situ) samples are shown in Figures 1(a) and 1(b). It can be seen that the spectrum of $\mathrm{Al}_{2} \mathrm{O}_{3}-\mathrm{SiO}_{2}(0.6)$ shows an amorphous form. The dispersive peak at $2 \theta \approx 24^{\circ}$ is characteristic of noncrystalline $\mathrm{SiO}_{2}$, which is observed in both patterns (Figures $1(\mathrm{a})$ and 1(b)). After in situ polymerization of $\mathrm{Al}_{2} \mathrm{O}_{3}$ and $\mathrm{SiO}_{2}$ by 4vinylpyridine, the peaks at $2 \theta \approx 17^{\circ}$ and $28^{\circ}$ corresponding to the crystalline mullite phase are observed [14].

The FT-IR spectra of optimized polymer-supported samples are shown in Figure 2. The characteristic band at 1080$1100 \mathrm{~cm}^{-1}$ is due to the $\mathrm{Si}-\mathrm{O}$ and $\mathrm{Al}-\mathrm{O}$ stretching vibrations, which is seen in all samples. The absorption band for $\mathrm{H}-$ $\mathrm{O}-\mathrm{H}$ bending vibration in water is around $1620-1650 \mathrm{~cm}^{-1}$ and $950 \mathrm{~cm}^{-1}$. The spectra showed a broad band around $3100-3600 \mathrm{~cm}^{-1}$, which is due to adsorbed water molecules. In the FT-IR spectra of composites (Figures 2(b), 2(d), and 2(f)), the new bands between 1410 and $1650 \mathrm{~cm}^{-1}$ are the characteristic absorptions of pyridine ring. Among them, the band appeared around $1600 \mathrm{~cm}^{-1}$ is attributed to the stretching vibration absorption of $\mathrm{C}-\mathrm{N}$ bond, and the others are attributed to the stretching vibration absorption of $\mathrm{C}=\mathrm{C}$ bond. In addition, the presence of peaks around $2900-3050 \mathrm{~cm}^{-1}$ corresponds to the aromatic and aliphatic $\mathrm{C}-\mathrm{H}$ stretching, and the vibration at $856 \mathrm{~cm}^{-1}$ is for $\mathrm{C}-\mathrm{H}$ deformation out of plane.

$\mathrm{N}_{2}$ adsorption-desorption is a common method to characterize mesoporous materials. This method provides information about the specific surface area, average pore diameter and pore volume, and so forth. The nitrogen adsorptiondesorption isotherm and structure data of the synthesized materials are presented in Figure 3 and Table 1, respectively. 
TABLE 1: BET surface area and pore size analysis of the samples.

\begin{tabular}{lcccc}
\hline Catalyst & $\begin{array}{c}\text { BET surface area } \\
\left(\mathrm{m}^{2} / \mathrm{g}\right)\end{array}$ & $\begin{array}{c}\text { Pore volume } \\
\left(\mathrm{cm}^{3} / \mathrm{g}\right)\end{array}$ & $\begin{array}{c}\text { Average pore diameter } \\
(\mathrm{nm})\end{array}$ & $\begin{array}{c}\text { C constant } \\
\left(\mathrm{m}^{2} / \mathrm{g}\right)\end{array}$ \\
\hline $\mathrm{Al}_{2} \mathrm{O}_{3}-\mathrm{SiO}_{2}(0.6)$ & 45.5 & 0.17 & 15.48 & 137.93 \\
$\mathrm{P}_{\mathrm{VPP}} / \mathrm{Al}_{2} \mathrm{O}_{3}-\mathrm{SiO}_{2}(0.6)$ (in-situ) & 20.8 & 0.20 & 39.04 & 36.29 \\
\hline
\end{tabular}

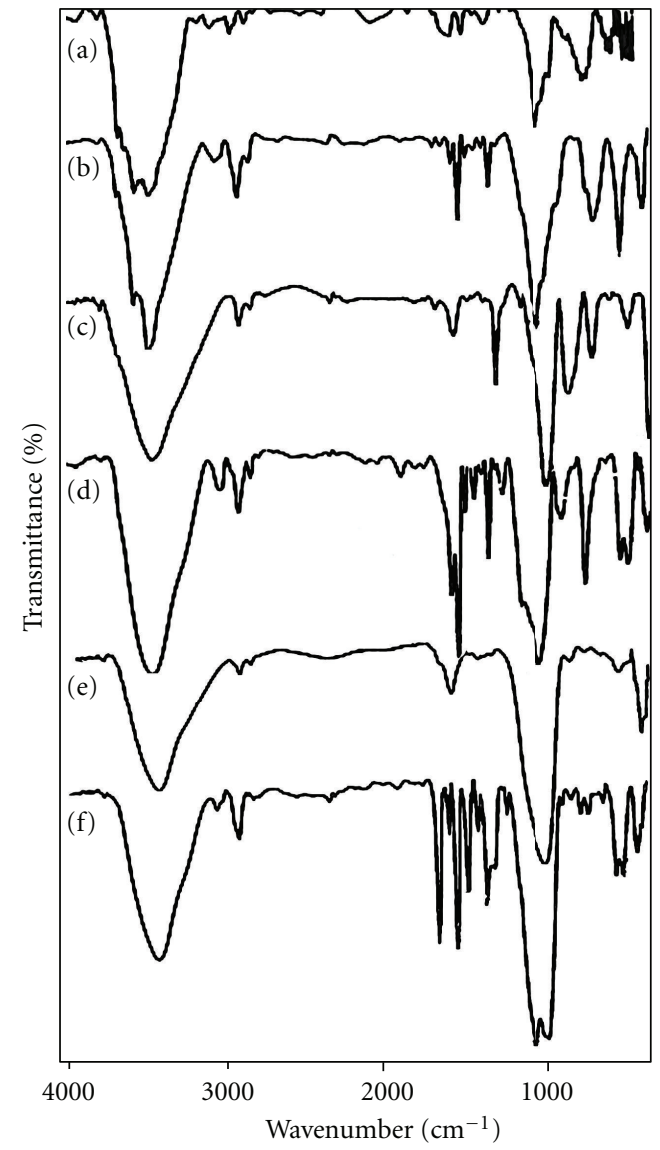

FIgURE 2: FT-IR spectra of (a) $\mathrm{Al}_{2} \mathrm{O}_{3}$, (b) $\mathrm{P} 4 \mathrm{VP} / \mathrm{Al}_{2} \mathrm{O}_{3}$, (c) $\mathrm{SiO}_{2}$, (d) $\mathrm{P} 4 \mathrm{VP} / \mathrm{SiO}_{2}$, (e) $\mathrm{Al}_{2} \mathrm{O}_{3}-\mathrm{SiO}_{2}(0.6)$, and (f) $\mathrm{P} 4 \mathrm{VP} / \mathrm{Al}_{2} \mathrm{O}_{3}-\mathrm{SiO}_{2}(0.6)$ (in situ).

Polymerization of 4-vinylpyridine in the $\mathrm{Al}_{2} \mathrm{O}_{3}-\mathrm{SiO}_{2}$ structure led to a reduction in the specific surface area, which is probably due to the presence of poly(4-vinylpyridine) on the surface of catalyst. On the other hand, the data for the $\mathrm{P} 4 \mathrm{VP} / \mathrm{Al}_{2} \mathrm{O}_{3}-\mathrm{SiO}_{2}(0.6)$ (in situ) sample indicated a growth in the pore volume and pore diameter in comparison to $\mathrm{Al}_{2} \mathrm{O}_{3}-\mathrm{SiO}_{2}$. The results are likely attributed to the presence of poly(4-vinylpyridine) in the structure of catalyst. Moreover, the amount of surface $\mathrm{OH}$ of the $\mathrm{Al}_{2} \mathrm{O}_{3}-\mathrm{SiO}_{2}$ was eliminated upon polymerization which is why the $C$ constant value of the BET equation decreased from 137.93 to 103.15 for $\mathrm{Al}_{2} \mathrm{O}_{3}-\mathrm{SiO}_{2}$ and $\mathrm{P} 4 \mathrm{VP} / \mathrm{Al}_{2} \mathrm{O}_{3}-\mathrm{SiO}_{2}$, respectively. Similarly, the surface area determined by $\mathrm{BJH}$ theory using the cumulative area of the pores also showed a significant drop $\left(S_{\mathrm{BJH}}\right.$ $\left(\mathrm{m}^{2} / \mathrm{g}\right): 36.29$ and 14.80 for $\mathrm{Al}_{2} \mathrm{O}_{3}-\mathrm{SiO}_{2}$ and $\mathrm{P} 4 \mathrm{VP} / \mathrm{Al}_{2} \mathrm{O}_{3}$ $\mathrm{SiO}_{2}$, resp.). According to the structure data of materials, it

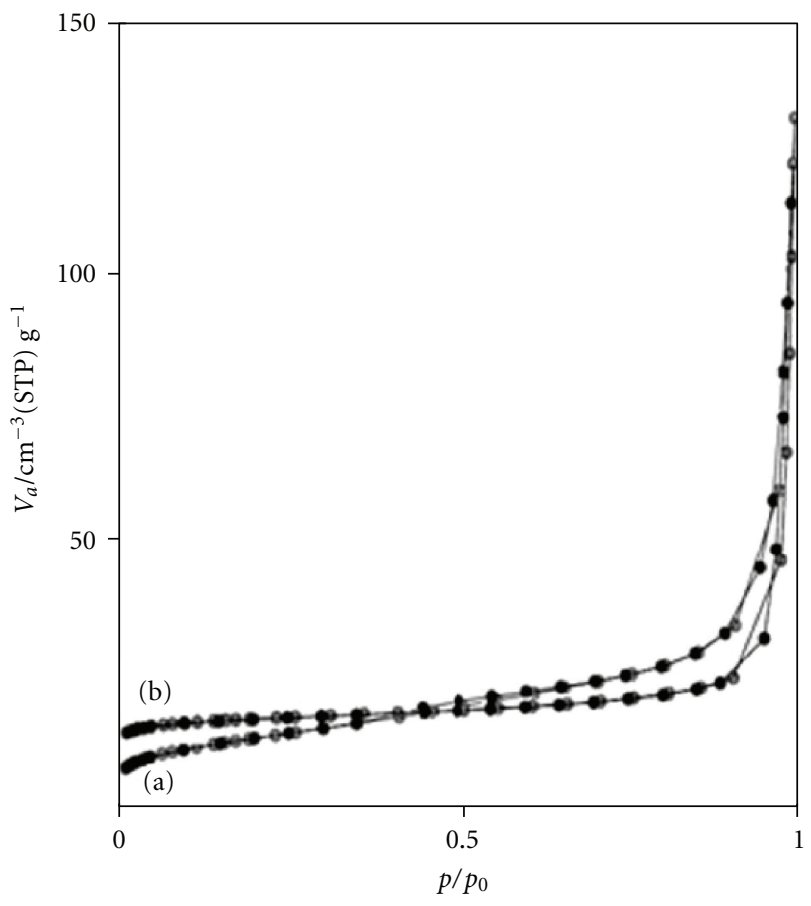

FIGURE 3: Nitrogen adsorption-desorption isotherm at $77 \mathrm{~K}$ : (a) $\mathrm{Al}_{2} \mathrm{O}_{3}-\mathrm{SiO}_{2}(0.6)$ and (b) $\mathrm{P} 4 \mathrm{VP} / \mathrm{Al}_{2} \mathrm{O}_{3}-\mathrm{SiO}_{2}(0.6)$ (in situ).

can be said that the synthesized catalyst has nanosize pores, which is a suitable candidate for nanocatalyst for chemical purposes.

The SEM images of the polymer-supported $\mathrm{Al}_{2} \mathrm{O}_{3}-\mathrm{SiO}_{2}$ are shown in Figures 4(a) and 4(b). These figures show the external surface morphology of the $\mathrm{Al}_{2} \mathrm{O}_{3}-\mathrm{SiO}_{2}$ before (Figure 4(a)) and after the polymerization of 4-vinylpyridine (Figure 4(b)). It can be seen that the poly(4-vinylpyridine) particles distribute on the $\mathrm{Al}_{2} \mathrm{O}_{3}-\mathrm{SiO}_{2}$ surface.

3.2. Catalytic Activity. The Knoevenagel condensation of benzaldehyde with ethyl cyanoacetate was chosen as a model reaction to test the catalytic activity of the poly(4vinylpyridine) $/ \mathrm{Al}_{2} \mathrm{O}_{3}-\mathrm{SiO}_{2}$. Thus, the effect of various reaction parameters on the condensation of benzaldehyde with ethyl cyanoacetate was studied using $\mathrm{P} 4 \mathrm{VP} / \mathrm{Al}_{2} \mathrm{O}_{3}-\mathrm{SiO}_{2}$ as a catalyst.

The variation of catalytic activity with changes in the $\mathrm{Al} / \mathrm{Si}$ molar ratio of catalyst was studied, and the results are given in Table 2 . It can be noted that the catalytic activity increases as the $\mathrm{Al} / \mathrm{Si}$ molar ratio decreases. Moreover, the catalytic activity of poly(4-vinylpyridine) $/ \mathrm{Al}_{2} \mathrm{O}_{3}-\mathrm{SiO}_{2}$ prepared by in situ and impregnated methods was compared. 


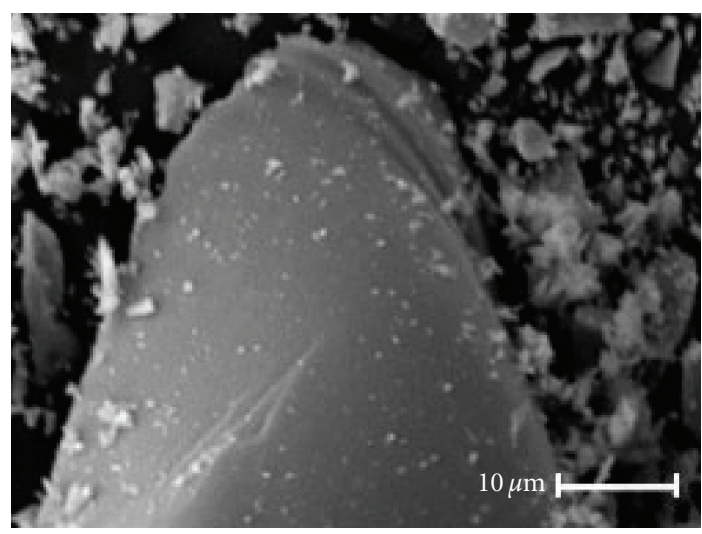

(a)

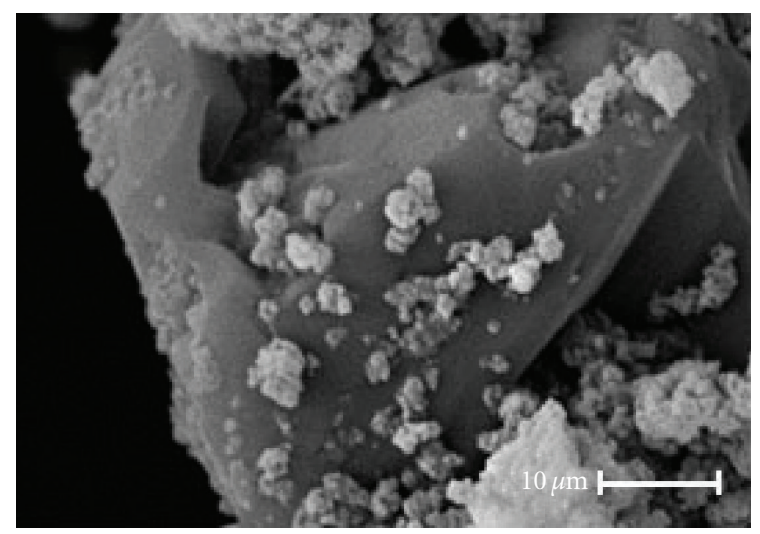

(b)

Figure 4: SEM images of (a) $\mathrm{Al}_{2} \mathrm{O}_{3}-\mathrm{SiO}_{2}(0.6)$ and (b) $\mathrm{P} 4 \mathrm{VP} / \mathrm{Al}_{2} \mathrm{O}_{3}-\mathrm{SiO}_{2}(0.6)$ (in situ).

TABLE 2: Effect of the Al/Si molar ratio on the catalytic activity of $\mathrm{P} 4 \mathrm{VP} / \mathrm{Al}_{2} \mathrm{O}_{3}-\mathrm{SiO}_{2}{ }^{\mathrm{a}}$.

\begin{tabular}{lc}
\hline Catalyst & Yield $^{\mathrm{b}}(\%)$ \\
\hline $\mathrm{P} 4 \mathrm{VP} / \mathrm{Al}_{2} \mathrm{O}_{3}-\mathrm{SiO}_{2}(1.66)$ (in-situ) & 91 \\
$\mathrm{P} 4 \mathrm{VP} / \mathrm{Al}_{2} \mathrm{O}_{3}-\mathrm{SiO}_{2}(1)$ (in-situ) & 93 \\
$\mathrm{P} 4 \mathrm{VP} / \mathrm{Al}_{2} \mathrm{O}_{3}-\mathrm{SiO}_{2}(0.6)$ (in-situ) & 98 \\
$\mathrm{P} 4 \mathrm{VP} / \mathrm{Al}_{2} \mathrm{O}_{3}-\mathrm{SiO}_{2}(0.6)(\mathrm{imp})$ & 48 \\
\hline
\end{tabular}

Reaction conditions: catalyst $(0.12 \mathrm{~g})$, benzaldehyde $(2 \mathrm{mmol})$, ethyl cyanoacetate $(2 \mathrm{mmol})$, reflux, $\mathrm{H}_{2} \mathrm{O}(10 \mathrm{~mL})$, reaction time $=30 \mathrm{~min}$, selectivity $=$ $100 \%$. ${ }^{\mathrm{b}}$ Isolated yield.

TABLE 3: Effect of active methylene reagents on the Knoevenagel condensation over $\mathrm{P} 4 \mathrm{VP} / \mathrm{Al}_{2} \mathrm{O}_{3}-\mathrm{SiO}_{2}$ (in-situ) ${ }^{\mathrm{a}}$.

\begin{tabular}{lcc}
\hline Active methylene reagent & Time $(\mathrm{min})$ & Yield $^{\mathrm{b}}(\%)$ \\
\hline Ethyl cyanoacetate & 30 & 98 \\
Diethyl malonate & 360 & - \\
Acetoacetic ester & 30 & 28 \\
\hline
\end{tabular}

Reaction conditions: catalyst ( $\mathrm{P} 4 \mathrm{VP} / \mathrm{Al}_{2} \mathrm{O}_{3}-\mathrm{SiO}_{2}(0.6)$ (in-situ), $0.12 \mathrm{~g}$ ), benzaldehyde $(2 \mathrm{mmol})$, active methylene reagent $(2 \mathrm{mmol})$, reflux, $\mathrm{H}_{2} \mathrm{O}$ $(10 \mathrm{~mL})$, and selectivity $=100 \% .{ }^{\mathrm{b}}$ Isolated yield.

Polymer-supported surface acts as the proton scavenger to generate ethyl cyanoacetate anion, which acts as the attacking reagent. It attacks the carbonyl group of benzaldehyde and in subsequent steps produces arylidene derivative. When in situ method was used for the preparation of the catalyst, the polymerization of 4-vinylpyridine (4VP) was done in the presence of aluminium isopropoxide and tetraethyl orthosilicate. Therefore, the poly(4-vinylpyridine) has been dispersed properly in the structure of $\mathrm{Al}_{2} \mathrm{O}_{3}-\mathrm{SiO}_{2}$ compared to impregnated method. Moreover, the results of back titration show that the amount of basic sites of $\mathrm{P} 4 \mathrm{VP} / \mathrm{Al}_{2} \mathrm{O}_{3}-\mathrm{SiO}_{2}$ prepared by in situ method is more than $\mathrm{P} 4 \mathrm{VP} / \mathrm{Al}_{2} \mathrm{O}_{3}-\mathrm{SiO}_{2}$ prepared by impregnated method. Hence, the organic polymer surface is more evenly distributed on the support surface in the case of the in situ method than impregnated method. Therefore, the former is more efficient as a basic catalyst than the latter
TABLE 4: Effect of solvent on the Knoevenagel condensation over $\mathrm{P} 4 \mathrm{VP} / \mathrm{Al}_{2} \mathrm{O}_{3}-\mathrm{SiO}_{2}$ (in-situ) ${ }^{\mathrm{a}}$.

\begin{tabular}{lc}
\hline Solvent & Yield $^{\mathrm{b}}(\%)$ \\
\hline Water & 98 \\
Methanol & 47 \\
Ethanol & 55 \\
Dichloromethane & 0 \\
Chloroform & 0 \\
Acetonitrile & 0 \\
Cyclohexane & 0 \\
Toluene & 0 \\
Solvent-free & 95 \\
\hline
\end{tabular}

Reaction conditions: catalyst $\left(\mathrm{P} 4 \mathrm{VP} / \mathrm{Al}_{2} \mathrm{O}_{3}-\mathrm{SiO}_{2}(0.6)\right.$ (in-situ), $\left.0.12 \mathrm{~g}\right)$, benzaldehyde $(2 \mathrm{mmol})$, ethyl cyanoacetate $(2 \mathrm{mmol})$, reflux, solvent $(10 \mathrm{~mL})$, reaction time $=30 \mathrm{~min}$, and selectivity $=100 \%$. ${ }^{\mathrm{b}}$ Isolated yield. ${ }^{\mathrm{c}}$ Reaction temperature $=80^{\circ} \mathrm{C}$. time $=50 \mathrm{~min}$.

TABLE 5: Effect of reaction temperature on the Knoevenagel condensation over $\mathrm{P} 4 \mathrm{VP} / \mathrm{Al}_{2} \mathrm{O}_{3}-\mathrm{SiO}_{2}$ (in-situ) ${ }^{\mathrm{a}}$.

\begin{tabular}{lcc}
\hline Temperature $\left({ }^{\circ} \mathrm{C}\right)$ & Time $(\min )$ & Yield $^{\mathrm{b}}(\%)$ \\
\hline Room temperature & 75 & 63 \\
40 & 60 & 70 \\
95 & 30 & 98 \\
\hline
\end{tabular}

Reaction conditions: catalyst ( $\mathrm{P} 4 \mathrm{VP} / \mathrm{Al}_{2} \mathrm{O}_{3}-\mathrm{SiO}_{2}(0.6)$ (in-situ), $0.12 \mathrm{~g}$ ), benzaldehyde $(2 \mathrm{mmol})$, ethyl cyanoacetate $(2 \mathrm{mmol}), \mathrm{H}_{2} \mathrm{O}(10 \mathrm{~mL})$, and selectivity $=100 \% .{ }^{b}$ Isolated yield.

and leads to a higher yield of Knoevenagel condensation of benzaldehyde by ethyl cyanoacetate.

The activity of $\mathrm{P} 4 \mathrm{VP} / \mathrm{Al}_{2} \mathrm{O}_{3}-\mathrm{SiO}_{2}$ for Knoevenagel condensation reaction was determined by using ethyl cyanoacetate, diethyl malonate, and acetoacetic ester as active methylene reagents (Table 3 ). It may be observed that the substrates have acidic methylene groups with $\mathrm{pK}_{\mathrm{a}}$ near 9 and 11 (ethyl cyanoacetate and acetoacetic ester, resp.) and it can be deprotonated by the catalyst to generate the corresponding carbanion, followed by attacking an electron acceptor center. 
TABLE 6: Effect of various supports on the Knoevenagel condensation $^{\mathrm{a}}$.

\begin{tabular}{lcc}
\hline Catalyst & Time (min) & Yield $^{\mathrm{b}}(\%)$ \\
\hline $\mathrm{Al}_{2} \mathrm{O}_{3}-\mathrm{SiO}_{2}(0.6)$ & 30 & 8 \\
$\mathrm{P}_{4} \mathrm{VP} / \mathrm{Al}_{2} \mathrm{O}_{3}-\mathrm{SiO}_{2}(0.6)$ (in-situ) & 30 & 98 \\
$\mathrm{P} 4 \mathrm{VP} / \mathrm{Al}_{2} \mathrm{O}_{3}$ & 120 & 87 \\
$\mathrm{P} 4 \mathrm{VP} / \mathrm{SiO}_{2}$ & 10 & 55
\end{tabular}

Reaction conditions: catalyst $(0.04 \mathrm{~g})$, benzaldehyde $(2 \mathrm{mmol})$, ethyl cyanoacetate $(2 \mathrm{mmol})$, reflux, $\mathrm{H}_{2} \mathrm{O}(10 \mathrm{~mL})$, and selectivity $=100 \% .{ }^{\mathrm{b}}$ Isolated yield.

Moreover, it has been found that the catalyst is not able to pull off protons from diethyl malonate $\left(\mathrm{pK}_{\mathrm{a}} \approx 13\right)$ and the Knoevenagel reaction with this substrate was not obtained. This observation is a further support that the catalyst has surface basic sites with $\mathrm{pK}_{\mathrm{a}}$ lower than 13 to carry up the reaction. It is obvious from the table that the highest benzaldehyde yield (98\%) was obtained using ethyl cyanoacetate.

Different solvents including water, acetonitrile, methanol, ethanol, dichloromethane, chloroform, cyclohexane, and toluene were used for the Knoevenagel condensation over $\mathrm{P} 4 \mathrm{VP} / \mathrm{Al}_{2} \mathrm{O}_{3}-\mathrm{SiO}_{2}(0.6)$ (in situ). The solvent-free condition was studied as well. The results are summarized in Table 4 . It can be seen that both solvent and solvent-free conditions represent good results. The highest yield of $98 \%$ was obtained using water as a solvent, indicating the effect of solvent on the reaction product. The solvation energy decreases by increasing polarity of the solvent. This clearly indicates that the reactants, intermediates, and products are more stabilized when polarity of solvent increases [15]. Thus, the reactants, intermediates, and product in water are more stable in comparison to other organic solvents. Solvents play a crucial role in the reaction by stabilizing ionic charges and providing an alternative lower energy pathway with which the reaction may proceed.

The effect of reaction temperature was studied to establish the importance of activation energy in this reaction. Condensation was performed between room temperature and reflux condition $\left(95^{\circ} \mathrm{C}\right.$ ) using $\mathrm{P} 4 \mathrm{VP} / \mathrm{Al}_{2} \mathrm{O}_{3}-\mathrm{SiO}_{2}(0.6)$ (in situ) as a catalyst, keeping other parameters constant (Table 5). The percentage of yield surged along with increasing reaction temperature from $63 \%$ at room temperature to $98 \%$ at $95^{\circ} \mathrm{C}$. In general, the Knoevenagel condensation is an endothermic reaction, which indicates that a higher temperature can promote the reaction.

As far as the amount of catalyst is concerned, the variation of catalytic activity was investigated by different amounts of the catalyst, and the results are shown in Figure 5. It is not of practical interest to use a large amount of catalyst. It is observed that while the amount of $\mathrm{P} 4 \mathrm{VP} / \mathrm{Al}_{2} \mathrm{O}_{3}-\mathrm{SiO}_{2}(0.6)$ (in situ) increases from 0.02 to $0.04 \mathrm{~g}$, the product yield rises from $92 \%$ to $98 \%$. It is because of the availability of more basic sites, which favors the dispersion of more active species. Afterwards, the percentage of yield remains stable at $98 \%$ between $0.04 \mathrm{~g}$ and $0.12 \mathrm{~g}$. It can be noted that the amount of catalyst used in the Knoevenagel reaction is little. Therefore, in this case, this composite is highly desirable.

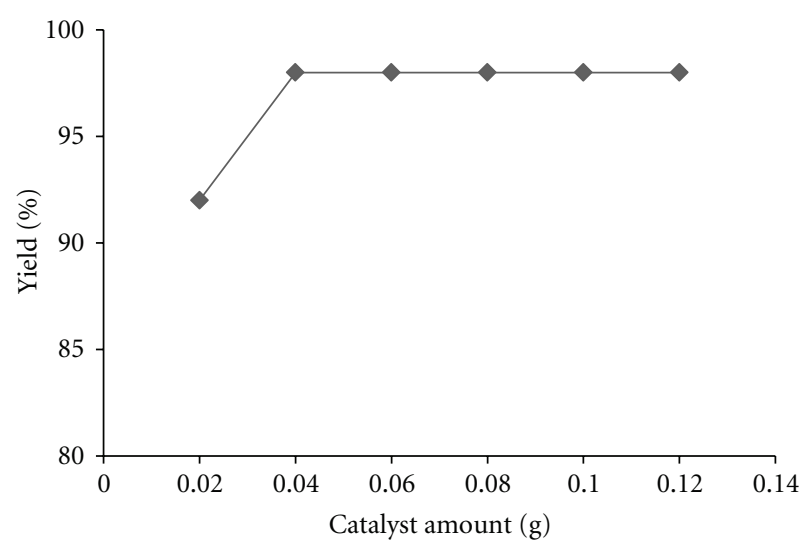

FIgURE 5: Effect of catalyst amount on the Knoevenagel condensation over $\mathrm{P} 4 \mathrm{VP} / \mathrm{Al}_{2} \mathrm{O}_{3}-\mathrm{SiO}_{2}$. Reaction conditions: catalyst ( $\mathrm{P} 4 \mathrm{VP} / \mathrm{Al}_{2} \mathrm{O}_{3}-\mathrm{SiO}_{2}(0.6)$ (in situ)), benzaldehyde ( $2 \mathrm{mmol}$ ), ethyl cyanoacetate $(2 \mathrm{mmol})$, reflux, $\mathrm{H}_{2} \mathrm{O}(10 \mathrm{~mL})$, reaction time $=$ $30 \mathrm{~min}$, and selectivity $=100 \%$.

In order to investigate the importance of support, the Knoevenagel reaction between benzaldehyde and ethyl cyanoacetate over $\mathrm{P} 4 \mathrm{VP} / \mathrm{Al}_{2} \mathrm{O}_{3}$ and $\mathrm{P} 4 \mathrm{VP} / \mathrm{SiO}_{2}$ was examined under optimum conditions, and the results were compared to $\mathrm{P} 4 \mathrm{VP} / \mathrm{Al}_{2} \mathrm{O}_{3}-\mathrm{SiO}_{2}$ (in situ) (Table 6). As mentioned in previous section, among these three types of catalysts, $\mathrm{P} 4 \mathrm{VP} / \mathrm{Al}_{2} \mathrm{O}_{3}-\mathrm{SiO}_{2}$ (in situ) had the most basic sites. Therefore, it showed the highest yield to the desired product. The activity of $\mathrm{Al}_{2} \mathrm{O}_{3}-\mathrm{SiO}_{2}$ as a catalyst in the Knoevenagel reaction was also investigated. In this case, the yield of $8 \%$ was observed after 30 minutes.

In order to examine the chemoselectivity of the catalyst, equal molar mixtures of ketone (4-nitro acetophenone) and aldehyde (4-nitro benzaldehyde) were allowed to react with ethyl cyanoacetate in water in the presence of the $\mathrm{P} 4 \mathrm{VP} / \mathrm{Al}_{2} \mathrm{O}_{3}-\mathrm{SiO}_{2}(0.6)$ (in situ) (Figure 6). The catalyst was able to discriminate between ketone and aldehyde and showed a high chemoselectivity (after five minutes, 100\% conversion for 4-nitro benzaldehyde was observed while 4nitro acetophenone remained unchanged).

In terms of green chemistry, reusability of the catalyst is highly preferable. Hence the recyclability of the catalyst was studied taking $\mathrm{P} 4 \mathrm{VP} / \mathrm{Al}_{2} \mathrm{O}_{3}-\mathrm{SiO}_{2}(0.6)$ (in situ) in the repeated experiments. In order to regenerate the catalyst, after the reaction it was separated from the reaction mixture by filtration and washed several times with deionized water and acetone. Then it was dried at $60^{\circ} \mathrm{C}$ and reused in the other reaction. Interestingly, it was observed that the activity of $\mathrm{P} 4 \mathrm{VP} / \mathrm{Al}_{2} \mathrm{O}_{3}-\mathrm{SiO}_{2}(0.6)$ (in situ) did not decrease after four cycles. Therefore, the present catalyst is an interesting candidate for commercial exploitation.

Application of $\mathrm{P} 4 \mathrm{VP} / \mathrm{Al}_{2} \mathrm{O}_{3}-\mathrm{SiO}_{2}$ in Knoevenagel Condensation of Various Aldehydes with Ethyl Cyanoacetate. Knoevenagel condensation of different aldehydes and ethyl cyanoacetate with poly(4-vinylpyridine) $/ \mathrm{Al}_{2} \mathrm{O}_{3}-\mathrm{SiO}_{2}$ (in situ) as a catalyst either in water or solvent-free conditions were investigated (Table 7). The results showed that the aromatic 
TABLE 7: Knoevenagel condensation reaction of aromatic and aliphatic aldehydes and ethyl cyanoacetate catalyzed by $\mathrm{P}_{4} \mathrm{VP} / \mathrm{Al}_{2} \mathrm{O}_{3}-\mathrm{SiO}_{2}{ }^{\mathrm{a}}$.

\begin{tabular}{|c|c|c|c|c|}
\hline Entry & Substrate & Product & $\begin{array}{l}\text { Time } \\
(\min )^{b}\end{array}$ & $\begin{array}{c}\text { Yield }^{c} \\
(\%)\end{array}$ \\
\hline 1 & & & $\begin{array}{l}30 \text { (I) } \\
75 \text { (II) }\end{array}$ & $\begin{array}{l}98 \\
98\end{array}$ \\
\hline 2 & & & $\begin{array}{l}5 \text { (I) } \\
5 \text { (II) }\end{array}$ & $\begin{array}{l}98 \\
98\end{array}$ \\
\hline 3 & & & $\begin{array}{l}60 \text { (I) } \\
60 \text { (II) }\end{array}$ & $\begin{array}{l}98 \\
70\end{array}$ \\
\hline 4 & & & $\begin{array}{l}30 \text { (I) } \\
60 \text { (II) }\end{array}$ & $\begin{array}{l}98 \\
90\end{array}$ \\
\hline 5 & & & $\begin{array}{l}10 \text { (I) } \\
20 \text { (II) }\end{array}$ & $\begin{array}{l}60 \\
40\end{array}$ \\
\hline 6 & & & $\begin{array}{l}45 \text { (I) } \\
45 \text { (II) }\end{array}$ & $\begin{array}{l}98 \\
60\end{array}$ \\
\hline 7 & & & $\begin{array}{l}5(\mathrm{I}) \\
5(\mathrm{II})\end{array}$ & $\begin{array}{l}98 \\
98\end{array}$ \\
\hline 8 & & & $\begin{array}{l}5(\mathrm{I}) \\
5 \text { (II) }\end{array}$ & $\begin{array}{l}98 \\
98\end{array}$ \\
\hline 9 & & & $\begin{array}{l}40 \text { (I) } \\
65 \text { (II) }\end{array}$ & $\begin{array}{l}90 \\
87\end{array}$ \\
\hline 10 & & & $\begin{array}{l}45 \text { (I) } \\
75 \text { (II) }\end{array}$ & $\begin{array}{l}93 \\
93\end{array}$ \\
\hline 11 & & & $\begin{array}{l}30 \text { (I) } \\
40 \text { (II) }\end{array}$ & $\begin{array}{l}92 \\
90\end{array}$ \\
\hline
\end{tabular}

$\bar{a}$ Reaction conditions: catalyst $(0.04 \mathrm{~g})$, ethyl cyanoacetate $(2 \mathrm{mmol})$, substrate $(2 \mathrm{mmol}), \mathrm{H}_{2} \mathrm{O}(10 \mathrm{~mL})$, and reflux. ${ }^{b}$ For (I) the solvent was $\mathrm{H}_{2} \mathrm{O}$, and for (II) solvent-free condition was chosen. ${ }^{\mathrm{C}}$ Isolated yield.

aldehydes, having different substituents such as chloro, nitro, methoxy, and methyl, were converted to the corresponding arylidene derivatives from good to high yields (60\% to $98 \%$ ) in both water and under solvent-free condition. Moreover, hetero-aromatic aldehydes such as furfural and 4-pyridine carbaldehyde also showed high yield (98\%) at very short run (Entries 7 and 8). The aromatic aldehydes with electronwithdrawing groups such as chloro and nitro proceeded at 


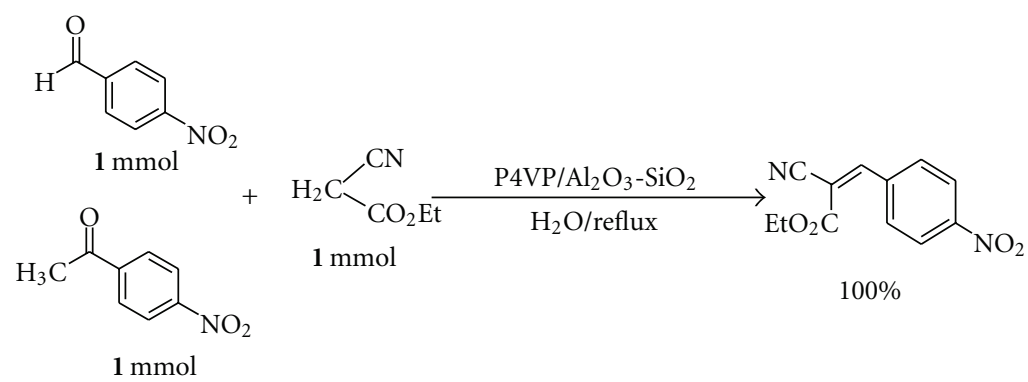

FIGURE 6: Reaction of 4-nitro acetophenone and 4-nitro benzaldehyde in the presence of the $\mathrm{P} 4 \mathrm{VP} / \mathrm{Al}_{2} \mathrm{O}_{3}-\mathrm{SiO}_{2}(0.6)$ (in situ).

faster rates than those with electron-donating groups such as methoxy and methyl. These results showed that electrondonating substituents in aromatic ring appear to retard the rate of reaction due to inactivation of aldehyde group. In addition, the Knoevenagel condensation was carried out using aliphatic aldehydes, which represented the high product yields (Entries 9 to 11). Interestingly, the results clearly established that the obtained products were E-isomer forms.

\section{Conclusions}

The novel nano-pore heterogeneous basic catalysts were synthesized and characterized by reaction of $4 \mathrm{VP}$ in the presence of different supports in various conditions. These new solid basic catalysts become practical alternatives to soluble bases regarding the following advantages: (a) high catalyst activity under mild reaction conditions; (b) easy separation of the catalyst after the reaction; (c) the desirable amount of catalyst; (d) excellent reusability of the catalyst for several repeated experiments. The catalytic activity of the catalyst prepared by in situ method is higher than impregnated method. Therefore, this synthesis method (in situ) can be very suitable for the preparation of composite catalysts.

\section{Acknowledgments}

Support from Islamic Azad University, Shahreza Branch (IAUSH) and Research Council and Center of Excellence in Chemistry is gratefully acknowledged.

\section{References}

[1] T. Suratwala, Z. Gardlund, K. Davidson et al., "Silylated coumarin dyes in sol-gel hosts. 2. Photostability and sol-gel processing," Chemistry of Materials, vol. 10, no. 1, pp. 199-209, 1998.

[2] C. Molina, K. Dahmouche, C. V. Santilli, A. F. Craievich, and S. J. L. Ribeiro, "Structure and luminescence of $\mathrm{Eu}^{3+}$-doped class I siloxane-poly(ethylene glycol) hybrids," Chemistry of Materials, vol. 13, no. 9, pp. 2818-2823, 2001.

[3] G. Jones, Organic Reactions, vol. 15, Wiley, New York, NY, USA, 1967.

[4] Y. Ono, "Solid base catalysts for the synthesis of fine chemicals," Journal of Catalysis, vol. 216, no. 1-2, pp. 406-415, 2003.
[5] A. Corma, S. Iborra, J. Primo, and F. Rey, "One-step synthesis of citronitril on hydrotalcite derived base catalysts," Applied Catalysis A, vol. 114, no. 2, pp. 215-225, 1994.

[6] Y. Zhang and C. Xia, "Magnetic hydroxyapatite-encapsulated $\gamma$ $\mathrm{Fe}_{2} \mathrm{O}_{3}$ nanoparticles functionalized with basic ionic liquids for aqueous Knoevenagel condensation," Applied Catalysis A, vol. 366, no. 1, pp. 141-147, 2009.

[7] A. Corma, S. Iborra, I. Rodríguez, and F. Sánchez, "Immobilized proton sponge on inorganic carriers: the synergic effect of the support on catalytic activity," Journal of Catalysis, vol. 211, no. 1, pp. 208-215, 2002.

[8] P. M. Price, J. H. Clark, and D. J. Macquarrie, "Modified silicas for clean technology," Journal of the Chemical Society, Dalton Transactions, no. 2, pp. 101-110, 2000.

[9] M. B. Gawande and R. V. Jayaram, "A novel catalyst for the Knoevenagel condensation of aldehydes with malononitrile and ethyl cyanoacetate under solvent free conditions," Catalysis Communications, vol. 7, no. 12, pp. 931-935, 2006.

[10] J. Han, Y. Xu, Y. Su, X. She, and X. Pan, "Guanidine-catalyzed Henry reaction and Knoevenagel condensation," Catalysis Communications, vol. 9, no. 10, pp. 2077-2079, 2008.

[11] R. J. Kalbasi, M. Kolahdoozan, A. Massah, and K. Shahabian, "Synthesis, characterization and application of poly(4-methyl vinylpyridinium hydroxide)/SBA-15 composite as a highly active heterogeneous basic catalyst for the Knoevenagel reaction," Bulletin of the Korean Chemical Society, vol. 31, no. 9, pp. 2618-2626, 2010.

[12] R. J. Kalbasi, M. Kolahdoozan, and S. M. Vanani, "Preparation, characterization and catalyst application of ternary interpenetrating networks of poly 4-methyl vinyl pyridinium hydroxide$\mathrm{SiO}_{2}-\mathrm{Al}_{2} \mathrm{O}_{3}$, Journal of Solid State Chemistry, vol. 184, no. 8, pp. 2009-2016, 2011.

[13] M. Ghiaci, B. Rezaei, and R. J. Kalbasi, "High selective $\mathrm{SiO}_{2}-\mathrm{Al}_{2} \mathrm{O}_{3}$ mixed-oxide modified carbon paste electrode for anodic stripping voltammetric determination of $\mathrm{Pb}(\mathrm{II})$," Talanta, vol. 73, no. 1, pp. 37-45, 2007.

[14] Q. Wei, D. Wang, S. Zhang, and C. Chen, "Preparation and characterization of sol-gel-derived unsupported $\mathrm{Al}_{2} \mathrm{O}_{3}-\mathrm{SiO}_{2}$ composite membranes," Journal of Alloys and Compounds, vol. 325, no. 1-2, pp. 223-229, 2001.

[15] Y. Wang, Z. C. Shang, T. X. Wu, J. C. Fan, and X. Chen, "Synthetic and theoretical study on proline-catalyzed Knoevenagel condensation in ionic liquid," Journal of Molecular Catalysis A, vol. 253, no. 1-2, pp. 212-221, 2006. 

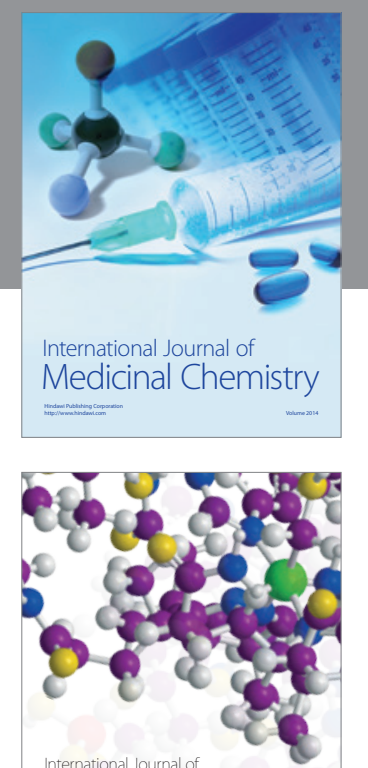

\section{Carbohydrate} Chemistry

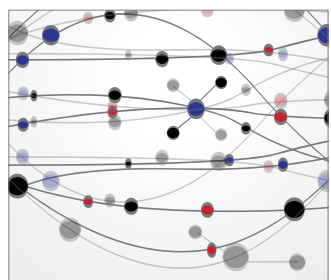

The Scientific World Journal
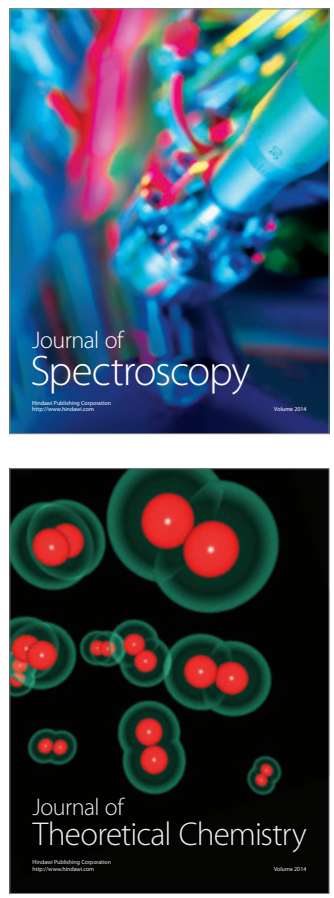
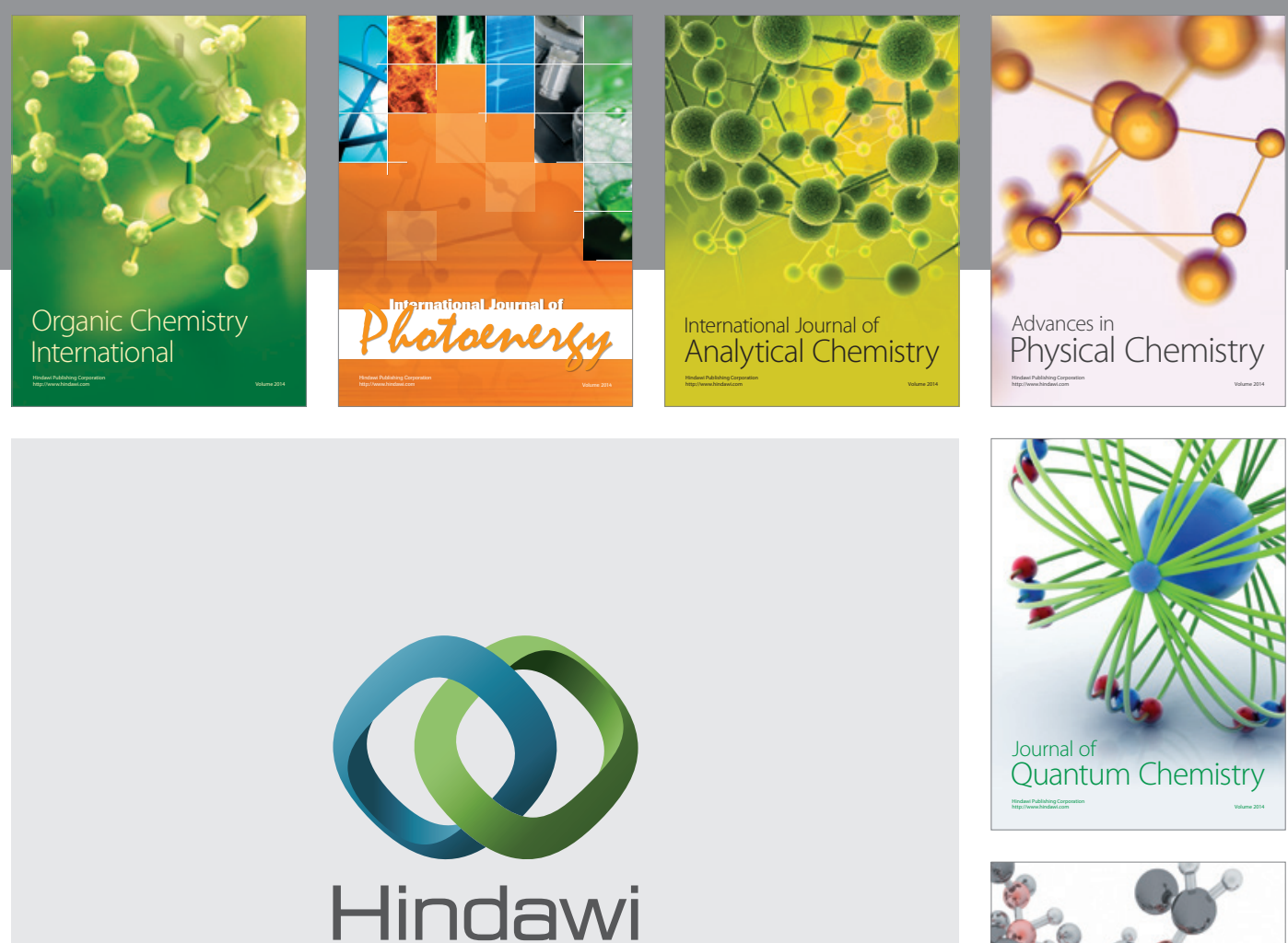

Submit your manuscripts at

http://www.hindawi.com

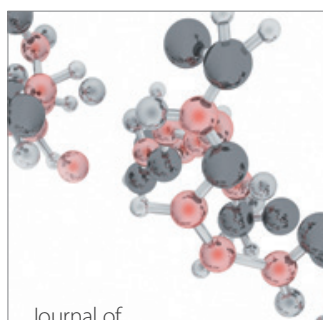

Analytical Methods

in Chemistry

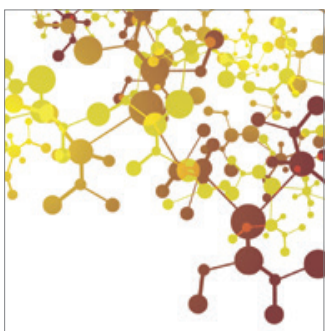

Journal of

Applied Chemistry

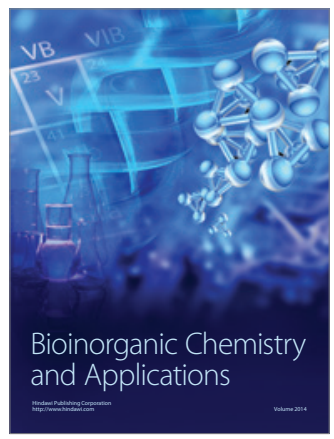

Inorganic Chemistry
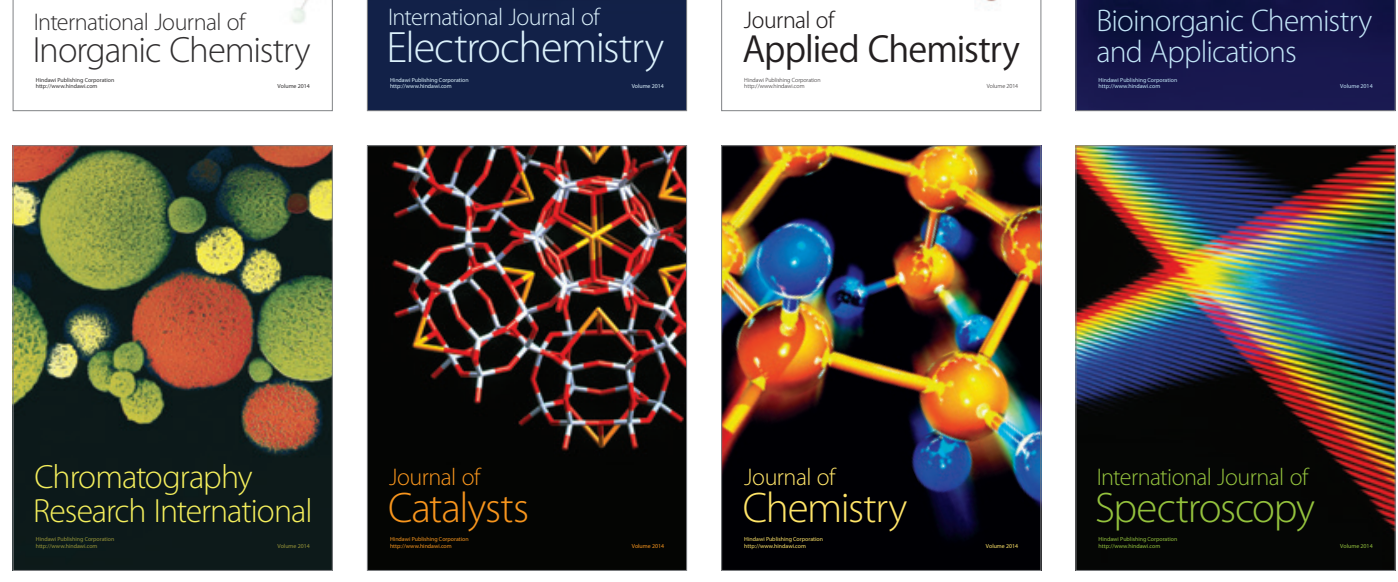